\title{
The Interpretation of Mathematical Difficulties in Primary School: Which Perspective to Choose?
}

\author{
Thomas Rajotte \\ Université du Québec en Abitibi-Témiscamingue, Rouyn-Noranda, Canada
}

\begin{abstract}
Research on learning difficulties in mathematics adopts one of two distinct perspectives. According to the first, learning difficulties are due to the intrinsic characteristics of the student. For supporters of the second perspective, those difficulties result from the interaction between the student and the school system. The objective of this study is to test the validity of these two perspectives in interpreting learning difficulties in mathematics among at-risk students. To this end, we collaborated with normally achieving (undiagnosed) and at-risk students. Results show that the second perspective is better suited to the interpretation of learning difficulties in mathematics students.
\end{abstract}

Keywords: mathematics, problem solving, learning difficulties, interpretation, intervention

\section{Introduction $^{1}$}

Since the reform of the (Quebec) education system in 2000, the proper integration and the success of students with learning difficulties have become major issues for the ministère de l'Éducation, du Loisir et du Sport (Squalli, Venet, \& Lessard, 2006). These issues are the core orientation of the Politique en adaptation scolaire (Government of Quebec, 1999). With regards to the prevention of learning difficulties, mathematics is one of the disciplines that deserve closer scrutiny. In fact, Deblois (2011) argues that our mathematical knowledge is constantly solicited, in the daily tasks as well as in the professional duties we are called upon to perform.

The analysis of several research papers reveals two distinct positions on the issue of students with learning difficulties in mathematics. The first is mostly focused on the identification and the description of problems related to the student himself or herself, while the second is more interested in the education system and the specific phenomena that define the relationships between the performance of the student, the effective teaching situation, and the specificity of the knowledge being transmitted (Giroux, 2010; Roiné, 2009). Martin and Mary (2010) support this position, adding that these two perspectives are at odds when it comes to explaining the specifics of mathematics as taught to students with difficulties.

These two perspectives are based on specific theoretical and methodological rationales and are supported by various (mostly academic) research sources. Moreover, they impact the way mathematics are being taught to a specific group of students and, by extension, they also impact the way this discipline is being learned by this same group of students. (Martin \& Mary, 2010, p. 230)

\footnotetext{
Thomas Rajotte, Professor, Université du Québec en Abitibi-Témiscamingue.

1 Another article about mathematical reasoning of ADHD students will be published in International Journal of Technology and Inclusive Education, vol 5(1).
} 
To this end, scientific research that uses developmental psychology, neuropsychology, and cognitive sciences in its explanatory framework is associated with the first perspective (Giroux, 2010; Goupil, 2007; Martin \& Mary, 2010). Supporters of this perspective argue that learning difficulties are directly related to the student. In fact, they appear to be intrinsically linked to the functional and structural characteristics of the learner (Lemoyne \& Lessard, 2003). By adopting this point of view, the student is perceived as a subject whose personal attributes can be measured by standardized assessment tools. Also, still according to this perspective, the role of the teacher is to help the student make up for his/her difficulties via remedial interventions aimed at modifying his/her cognitive processes. In this context, the student is cast in the role of the person that requires help. Incidentally, some studies show that the assistance mechanisms put into place do not always stimulate the cognitive and mathematical engagement of the student (Martin \& Mary, 2010). In that respect, Roiné (2009) mentions that difficulties in mathematics, as seen from this perspective, rest on the "specificity hypothesis", which states that teachers' interventions must be performed according to the classification of students into categories as performed in the school system.

Moreover, Lemoyne and Lessard (2003) point out that in the last decades, research on learning difficulties using cognitive sciences in its explanatory framework has yielded very little empirical results. According to these authors, this has led to a challenge of the immutable nature of the cognitive characteristics of learners and an investigation of the way school functions as an institution. Consequently, a second rationale has been developed for learning difficulties. It is essentially based on the didactics of mathematics. In this perspective, learning difficulties are seen as the result of the interaction between the student and the school system in which he/she participates. In this context, the learner is considered as a student (therefore a subject of the didactic system) whose difficulties are caused at least in part by the didactic contract ${ }^{2}$ binding him or her to the didactic system (Perrin-Glorian, 1993). Therefore, according to Roiné (2009), learning difficulties are, in this perspective, viewed through the lens of a "contract hypothesis".

This perspective considers teaching as the implementation of conditions that will encourage learning via didactic interventions that take into account the students' mathematical knowledge as well as the specificity of the knowledge being transmitted (Martin \& Mary, 2010). As for the students, they are modelled as active subjects who interact in a didactic environment developed by a teacher according to their cognitive dimensions and the characteristics of the knowledge to be learned (Mary, Squalli, \& Schmidt, 2008).

In order to describe the perspective adopted by the various disciplines that study learning difficulties in mathematics, Giroux (2010) developed a diagram that classifies these disciplines by finality or epistemological stance. This diagram, shown in Figure 1, translates the finality of these disciplines on a lateral axis. A shift towards the left of this axis symbolizes a growing interest in the study of cognitive functions. This implies a focus on individual characteristics. Incidentally, Giroux (2010) mentions that a shift towards the right end of the axis is the sign of a growing interest for the study of the way knowledge works in learning or teaching situations. This move involves a focus on the interactive phenomena required in the transmission and the acquisition of knowledge.

\footnotetext{
2 According to Brousseau (1998), the didactic contract allows the description of implicit or explicit rules governing the sharing of responsibilities in the transmission or the acquisition of knowledge between the teacher and the student. This contract is therefore a representation of the expectations of both parties.
} 


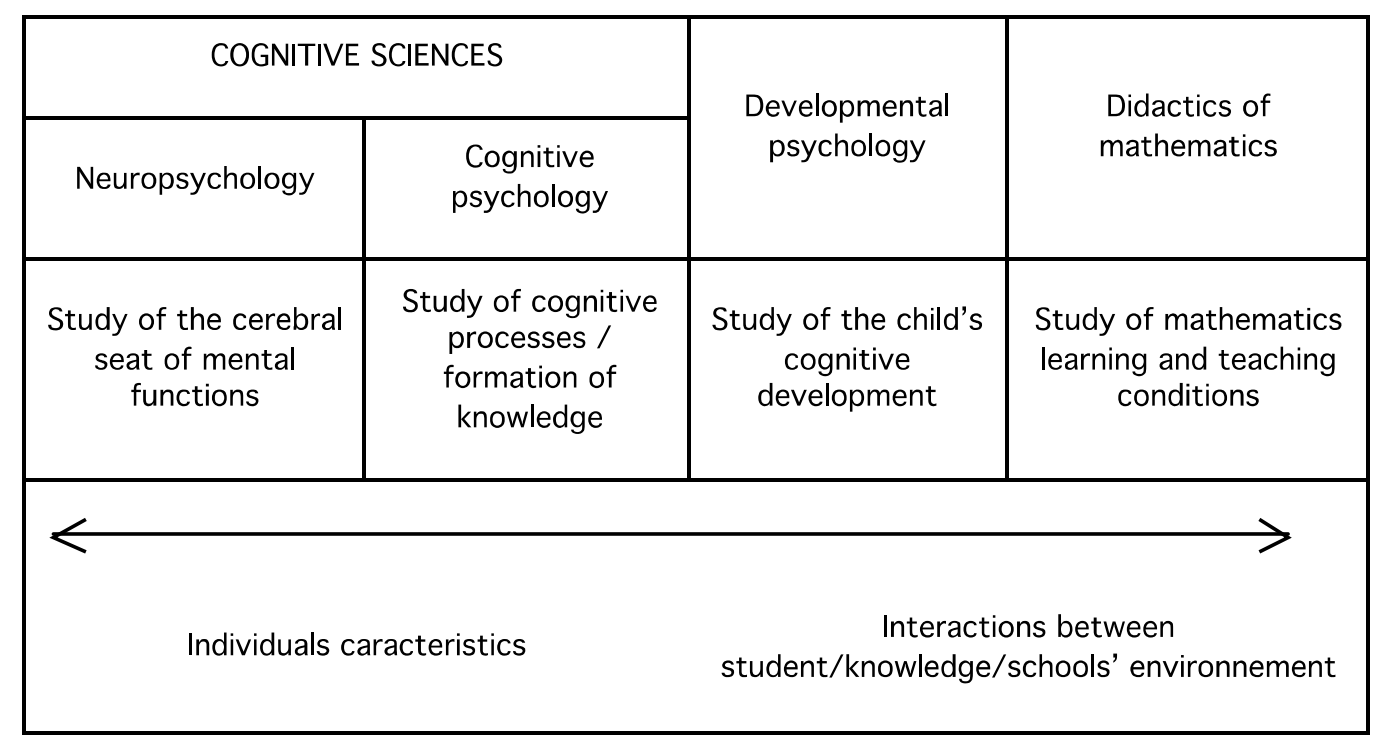

Figure 1. Organization of the disciplines that study difficulties in mathematics, according to Giroux (2010).

Based on the findings of Giroux (2010), it is possible to assume that supporters of the first perspective, which specifically includes research stemming from developmental psychology, neuropsychology, and cognitive sciences, will be located on the left side of the diagram. This is justified by the explanatory framework for learning difficulties in mathematics, where the focus is on individual characteristics, which has been adopted by researchers from these disciplines. On the opposite, supporters of the second perspective would be more specifically positioned on the right side of the diagram, as they are more focused on student interactions in a given didactic system.

\section{Departmental Position on Teaching Mathematics to Students With Difficulties}

The evolution of special education legislation and policies tends to align the position of the ministère de l'Éducation with the first perspective on students with difficulties. This position is stated in the Politique en adaptation scolaire (Gouvernement du Québec, 1999), developed to refocus the high-level guidelines of the education reform on special needs and the specifics of students with disabilities or adjustment or learning difficulties. This policy includes a ministerial directive to teachers, asking them to adapt their teaching to the needs and characteristics of their students (Gouvernement du Québec, 1999; Gouvernement du Québec, 2006; Ministère de l'Éducation du Québec, 2000a; Ministère de l'Éducation du Québec, 2000b).

Incidentally, it is appropriate to review the basis for the ministerial directive on the adaptation of teaching to the individual characteristics and needs of the students. To this end, Giroux (2007) mentions that the position of the ministère de l'Éducation of Québec is not based on the consideration of the didactic dimension of teaching and learning. In fact, the ministerial guidelines tend to implement teaching practices that constantly seek news ways to "bridge the gap" that separates the student with difficulties from the other students at the expense of the consideration of the specificity of the teaching contents and the didactic conditions that facilitate his/her learning. Also, even though the use of explanatory frameworks related to the didactics of mathematics is on the rise since the eighties (Lemoyne \& Lessard, 2003), these ministerial directives, because of their explanatory position on learning difficulties, neglect, in a way, the results achieved by the didactics of mathematics. 


\section{Research Objectives}

All these considerations lead to a challenge of the interpretation conditions of learning difficulties in mathematics. In this research project, we will explore the validity of both perspectives on learning difficulties. To this end, we will assess whether the intrinsic characteristics of the students, as operationalized by the label "at-risk student", are a valid explanatory framework for learning difficulties in mathematics. The goal of this approach is to test the "specificity hypothesis". Moreover, to test the second interpretative perspective, we will explore the influence of the structure of statements of mathematical problems and the affiliation with a given school environment on the emergence of learning difficulties. This approach will be used specifically to test the "contract hypothesis".

\section{Methodology}

\section{Sample}

The sample that we assembled allowed us to conduct our experiment on 522 sixth-grade elementary students. A total of 106 at-risk students, as well as 416 undiagnosed students, took part in the research project. The participants came from 28 schools of the Québec area.

\section{Variables Studied}

Several variables have been used in this research protocol. First, we considered the attribution of the "at-risk student" label to assess whether individual characteristics influenced the efficiency of problem-solving procedures used. The efficiency of the procedures used by at-risk students is compared with those of undiagnosed students. ${ }^{3}$ Then, to explore the influence of the adhesion to a specific learning community, we considered the class to which each student belonged.

\section{Difficulties in Mathematics}

In order to document the difficulties in mathematics encountered by at-risk students, we studied the relational calculus used to solve mathematical problems. More specifically, we analyzed the relational calculus developed in nine distinct problems on proportions. The problems varied according to the type of information presented: problems providing only the data essential to the resolution of the problem, problems providing situational elements of information, and statements providing superfluous elements of information. Also, our problem statements on proportions included three distinct types of numerical relationships: integer within relationship, integer between relationship as well as noninteger relationship. The characteristics of the nine problems that we used in our study are presented in Table 1.

Table 1

Presentation of the Structure of the Nine Problem Statements

\begin{tabular}{llll}
\hline & Essential data & Situational elements & Superfluous elements \\
\hline Integer within relationship & Problem \#5 & Problem \#2 & Problem \#6 \\
Integer between relationship & Problem \#4 & Problem \#1 & Problem \#7 \\
Noninteger relationship & Problem \#9 & Problem \#8 & Problem \#3 \\
\hline
\end{tabular}

\footnotetext{
3 The concept of "at-risk student" refers to any student who cannot be classified as an at-risk student, a student with disabilities and/or a student with adjustment or learning difficulties.
} 


\section{Statistical Analysis}

To meet our research objectives, we implemented three distinct statistical tests. First, to compare the efficiency of problem-solving procedures of at-risk and undiagnosed students, we performed chi-squared analyses for each of the nine problems. Then, to compare the level of difficulty implied by the structure of the problem statements, we performed paired t-tests for each problem pair. Finally, we performed an analysis of variance (ANOVA) and an analysis of covariance (ANCOVA) to explore the influence of the affiliation to a specific learning community. The goal of this analysis was to verify the existence of differences of performance in problem resolution between the various sixth grade classes with which we collaborated.

\section{Results}

\section{Comparison of the Relational Calculus of At-Risk and Undiagnosed Students}

To meet our first research objective, which is the comparison of the relational calculus of at-risk and undiagnosed students, we performed a chi-squared test for each of the problem statements. The results of the chi-squared tests are presented in Table 2. These analyses showed significant differences in the problem-solving procedures used in problems \#2 (chi-squared $=20.998 ; \mathrm{p}<0.001)$ and \#4 (chi-squared $=$ 15.517; $\mathrm{p}<0.001)$.

Table 2

Comparison of the Relational Calculus of At-Risk and Undiagnosed Students

\begin{tabular}{|c|c|c|c|c|c|c|}
\hline \multirow[b]{2}{*}{ Problem number } & \multicolumn{3}{|c|}{ Relational calculus used } & \multicolumn{3}{|c|}{ Chi-squared } \\
\hline & $\begin{array}{l}\text { Absence of a proportional } \\
\text { reasonning }\end{array}$ & $\begin{array}{l}\text { Presence of a } \\
\text { proportionnal reasoning }\end{array}$ & $\begin{array}{l}\text { Unclassifed } \\
\text { reasonning }\end{array}$ & Value & df & Sig. \\
\hline At-risk students & $25(23,6 \%)$ & $78(73,6 \%)$ & $3(2,8 \%)$ & \multirow{2}{*}{2,408} & \multirow{2}{*}{2} & \multirow{2}{*}{0,300} \\
\hline Undiagnosed students & $82(19,7 \%)$ & $329(79,1 \%)$ & $5(1,2 \%)$ & & & \\
\hline Problem $2 \quad$ At-risk students & $37(34,9 \%)$ & $48(45,3 \%)$ & $21(19,8 \%)$ & \multirow{2}{*}{20,998} & \multirow{2}{*}{2} & \multirow{2}{*}{$0,000 *$} \\
\hline$\overline{\text { Undiagnosed students }}$ & $99(27,2 \%)$ & $282(67,8 \%)$ & $35(8,4 \%)$ & & & \\
\hline Problem $3 \quad$ At-risk students & $59(55,7 \%)$ & $33(31,1 \%)$ & $14(13,2 \%)$ & \multirow{2}{*}{4,556} & \multirow{2}{*}{2} & \multirow{2}{*}{0,102} \\
\hline Undiagnosed students & $189(45,4 \%)$ & $176(42,3 \%)$ & $51(12,3 \%)$ & & & \\
\hline At-risk students & $22(20,8 \%)$ & $78(73,6 \%)$ & $6(5,7 \%)$ & \multirow{2}{*}{15,517} & \multirow{2}{*}{2} & \multirow{2}{*}{$0,000 *$} \\
\hline$\overline{\text { Undiagnosed students }}$ & $44(10,6 \%)$ & $366(88,0 \%)$ & $6(1,4 \%)$ & & & \\
\hline At-risk students & $56(52,8 \%)$ & $43(40,6 \%)$ & $7(6,6 \%)$ & \multirow{2}{*}{6,050} & \multirow{2}{*}{2} & \multirow{2}{*}{0,049} \\
\hline$\overline{\text { Undiagnosed students }}$ & $173(41,6 \%)$ & $224(53,8 \%)$ & $19(4,6 \%)$ & & & \\
\hline At-risk students & $56(52,8 \%)$ & $43(40,6 \%)$ & $7(6,6 \%)$ & \multirow{2}{*}{6,050} & \multirow{2}{*}{2} & \multirow{2}{*}{0,049} \\
\hline$\overline{\text { Undiagnosed students }}$ & $173(41,6 \%)$ & $224(53,8 \%)$ & $19(4,6 \%)$ & & & \\
\hline At-risk students & $38(35,8 \%)$ & $58(54,7 \%)$ & $10(9,4 \%)$ & \multirow{2}{*}{9,565} & \multirow{2}{*}{2} & \multirow{2}{*}{0,008} \\
\hline$\overline{\text { Undiagnosed students }}$ & $95(22,8 \%)$ & $293(70,4 \%)$ & $28(6,7 \%)$ & & & \\
\hline$\underline{\text { Problem } 8} \quad$ At-risk students & $59(55,7 \%)$ & $38(35,8 \%)$ & $9(8,5 \%)$ & \multirow{2}{*}{5,096} & \multirow{2}{*}{2} & \multirow{2}{*}{0,078} \\
\hline Undiagnosed students & $188(45,2 \%)$ & $200(48,1 \%)$ & $28(6,7 \%)$ & & & \\
\hline$\underline{\text { Problem } 9} \quad$ At-risk students & $53(50,0 \%)$ & $42(39,6 \%)$ & $11(10,4 \%)$ & \multirow{2}{*}{1,846} & \multirow{2}{*}{2} & \multirow{2}{*}{0,397} \\
\hline Undiagnosed student & $197(47,4 \%)$ & $189(45,4 \%)$ & $30(7,2 \%)$ & & & \\
\hline
\end{tabular}

\section{Comparison of the Level of Difficulty of the Problems}

To meet our second research objective, we compared the levels of difficulty of each of the mathematical problems. To this end, we performed a paired t-test for the various possible combinations of problem pairs. We conducted a total of 36 distinct paired t-tests, since there were 36 possible combinations. To address the inflation of the alpha, we performed the Bonferroni correction by dividing our level of significance by 36 for each of these 
tests. Consequently, our level of significance for each paired t-test was set to $p \leq 0.001(0.05 / 36)$. Conducting these tests allowed us to conclude that out of the 36 pairs of problems, 26 involved diverging levels of difficulty. The results of paired T-tests are presend in Table 3. These results show that statistically significant differences exist in terms of the difficulty involved in the majority of the problems selected in our research protocol. The prioritization of the levels of difficulty based on the structure of the problems is depicted in Figure 2. Moreover, the ordering of didactical variables according to their level of complexity is shown in Table 4.

Table 3

Results of the Paired T-tests for the Various Possible Combinations of Problem Pairs

\begin{tabular}{|c|c|c|c|c|c|c|c|c|}
\hline \multicolumn{9}{|l|}{ Paired T-tests } \\
\hline & \multicolumn{5}{|c|}{ Paired differences } & & \multirow{3}{*}{ df } & \multirow{3}{*}{ Sig (2-tailed) } \\
\hline & \multirow{2}{*}{ Mean } & \multirow{2}{*}{$\begin{array}{l}\text { Std. } \\
\text { Deviation }\end{array}$} & \multirow{2}{*}{$\begin{array}{l}\text { Std. Error } \\
\text { Mean }\end{array}$} & \multicolumn{2}{|c|}{$\begin{array}{c}95 \% \text { Confidence interval of } \\
\text { the difference }\end{array}$} & & & \\
\hline & & & & Lower & Upper & & & \\
\hline Pair 1 : Problems 1 and 2 & 0,66284 & 2,10048 & 0,09194 & 0,48223 & 0,84345 & 7,210 & 521 & $0,000^{*}$ \\
\hline Pair 2 : Problems 1 and 3 & 1,60920 & 2,11850 & 0,09272 & 1,42704 & 1,79135 & 17,355 & 521 & $0,000^{*}$ \\
\hline Pair 3 : Problems 1 and 4 & $-0,22605$ & 1,93727 & 0,08479 & $-0,39263$ & $-0,05948$ & $-2,666$ & 521 & 0,008 \\
\hline Pair 4 : Problems 1 and 5 & 1,12452 & 2,38715 & 0,10448 & 0,91926 & 1,32978 & 10,763 & 521 & $0,000^{*}$ \\
\hline Pair 5 : Problems 1 and 6 & 0,92529 & 2,26128 & 0,09897 & 0,73085 & 1,11972 & 9,349 & 521 & $0,000^{*}$ \\
\hline Pair 6 : Problems 1 and 7 & 0,65709 & 2,14163 & 0,09374 & 0,47294 & 0,84124 & 7,010 & 521 & $0,000 *$ \\
\hline Pair 7 : Problems 1 and 8 & 1,32759 & 2,01481 & 0,08819 & 1,15434 & 1,50083 & 15,054 & 521 & $0,000^{*}$ \\
\hline Pair 8 : Problems 1 and 9 & 1,36207 & 2,12587 & 0,09305 & 1,17928 & 1,54486 & 14,639 & 521 & $0,000^{*}$ \\
\hline Pair 9 : Problems 2 and 3 & 0,94636 & 2,23070 & 0,09763 & 0,75455 & 1,13817 & 9,693 & 521 & $0,000^{*}$ \\
\hline Pair 10 : Problems 2 and 4 & $-0,88889$ & 1,97565 & 0,08647 & $-1,05876$ & $-0,71901$ & $-10,280$ & 521 & $0,000^{*}$ \\
\hline Pair 11 : Problems 2 and 5 & 0,46169 & 2,30818 & 0,10103 & 0,26322 & 0,66015 & 4,570 & 521 & $0,000^{*}$ \\
\hline Pair 12 : Problems 2 and 6 & 0,26245 & 2,21626 & 0,09700 & 0,07189 & 0,45302 & 2,706 & 521 & 0,007 \\
\hline Pair 13 : Problems 2 and 7 & $-0,00575$ & 2,28110 & 0,09984 & $-0,20189$ & 0,19039 & $-0,058$ & 521 & 0,954 \\
\hline Pair 14 : Problems 2 and 8 & 0,66475 & 2,01260 & 0,08809 & 0,49170 & 0,83780 & 7,546 & 521 & $0,000^{*}$ \\
\hline Pair 15 : Problems 2 and 9 & 0,69923 & 2,26455 & 0,09912 & 0,50452 & 0,89395 & 7,055 & 521 & $0,000^{*}$ \\
\hline Pair 16 : Problems 3 and 4 & $-1,83525$ & 1,98354 & 0,08682 & $-2,00580$ & $-1,66469$ & $-21,139$ & 521 & $0,000^{*}$ \\
\hline Pair 17 : Problems 3 and 5 & $-0,48467$ & 2,33573 & 0,10223 & $-0,68551$ & $-0,28384$ & $-4,741$ & 521 & $0,000^{*}$ \\
\hline Pair 18 : Problems 3 and 6 & $-0,68391$ & 2,24200 & 0,09813 & $-0,87669$ & $-0,49113$ & $-6,969$ & 521 & $0,000^{*}$ \\
\hline Pair 19 : Problems 3 and 7 & $-0,95211$ & 2,33795 & 0,10233 & $-1,15314$ & $-0,75108$ & $-9,304$ & 521 & $0,000^{*}$ \\
\hline Pair 20 : Problems 3 and 8 & $-0,28161$ & 2,06497 & 0,09038 & $-0,45917$ & $-0,10405$ & $-3,116$ & 521 & 0,002 \\
\hline Pair 21 : Problems 3 and 9 & $-0,24713$ & 2,18840 & 0,09578 & $-0,43530$ & $-0,05896$ & $-2,580$ & 521 & 0,010 \\
\hline Pair 22 : Problems 4 and 5 & 1,35057 & 2,08589 & 0,09130 & 1,17122 & 1,52993 & 14,793 & 521 & $0,000^{*}$ \\
\hline Pair 23 : Problems 4 and 6 & 1,15134 & 2,05913 & 0,09013 & 0,97429 & 1,32840 & 12,775 & 521 & $0,000^{*}$ \\
\hline Pair 24 : Problems 4 and 7 & 0,88314 & 1,95824 & 0,08571 & 0,71476 & 1,05152 & 10,304 & 521 & $0,000^{*}$ \\
\hline Pair 25 : Problems 4 and 8 & 1,55364 & 1,93215 & 0,08457 & 1,38750 & 1,71978 & 18,372 & 521 & $0,000^{*}$ \\
\hline Pair 26 : Problems 4 and 9 & 1,58812 & 2,14827 & 0,09403 & 1,40340 & 1,77284 & 16,890 & 521 & $0,000^{*}$ \\
\hline Pair 27 : Problems 5 and 6 & $-0,19923$ & 2,17792 & 0,09533 & $-0,38650$ & $-0,01197$ & $-2,090$ & 521 & 0,037 \\
\hline Pair 28 : Problems 5 and 7 & $-0,46743$ & 2,38274 & 0,10429 & $-0,67231$ & $-0,26255$ & $-4,482$ & 521 & $0,000^{*}$ \\
\hline Pair 29 : Problems 5 and 8 & 0,20307 & 2,26823 & 0,09928 & 0,00803 & 0,39810 & 2,045 & 521 & 0,041 \\
\hline Pair 30 : Problems 5 and 9 & 0,23755 & 2,34809 & 0,10277 & 0,03565 & 0,43945 & 2,311 & 521 & 0,021 \\
\hline Pair 31 : Problems 6 and 7 & 0,26820 & 2,26568 & 0,09917 & 0,07338 & 0,46301 & 2,705 & 521 & 0,007 \\
\hline Pair 32 : Problems 6 and 8 & $-0,40230$ & 2,10178 & 0,09199 & $-0,58302$ & $-0,22158$ & $-4,373$ & 521 & $0,000^{*}$ \\
\hline Pair 33 : Problems 6 and 9 & $-0,43678$ & 2,30846 & 0,10104 & $-0,63528$ & $-0,23829$ & $-4,323$ & 521 & $0,000^{*}$ \\
\hline Pair 34 : Problems 7 and 8 & $-0,67050$ & 2,14240 & 0,09377 & $-0,85471$ & $-0,48628$ & $-7,150$ & 521 & $0,000^{*}$ \\
\hline Pair 35 : Problems 7 and 9 & $-0,70498$ & 2,44265 & 0,10691 & $-0,91501$ & $-0,49495$ & $-6,594$ & 521 & $0,000^{*}$ \\
\hline Pair 36 : Problems 8 and 9 & $-0,03448$ & 2,10446 & 0,09211 & $-0,21543$ & 0,14647 & $-0,374$ & 521 & 0,708 \\
\hline
\end{tabular}




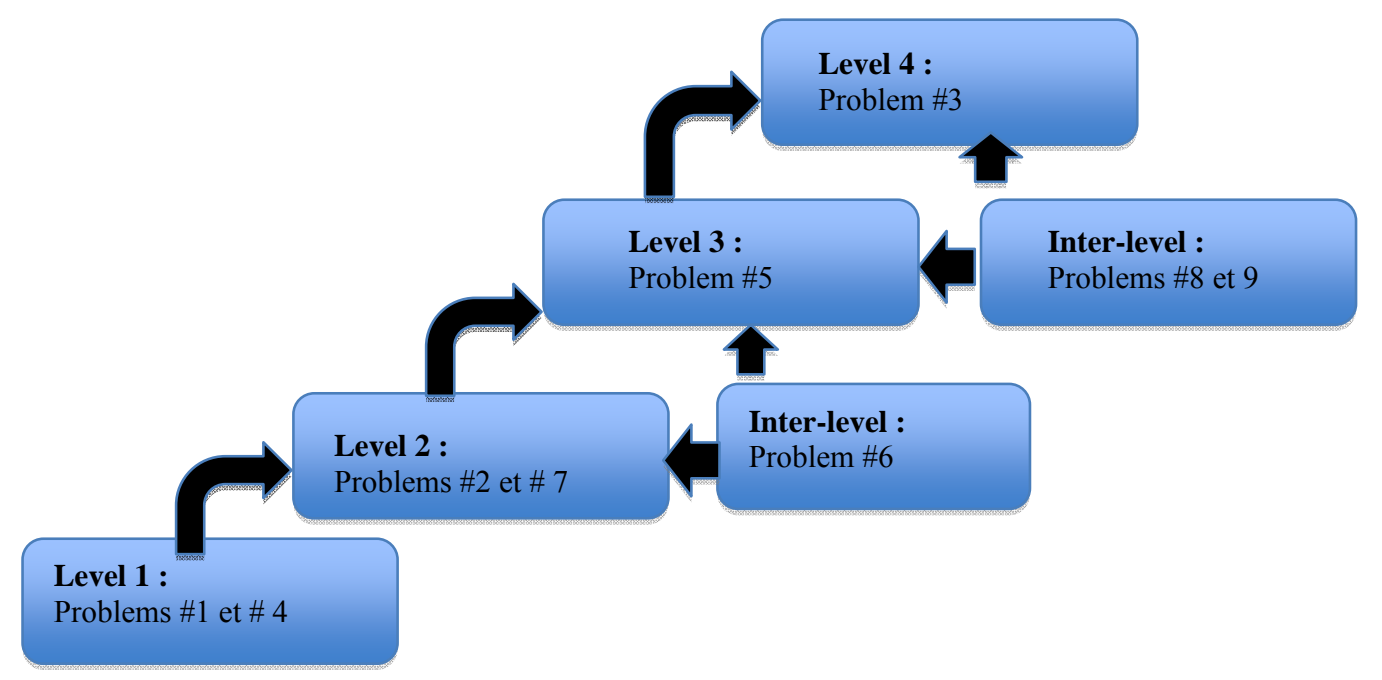

Figure 2. Prioritization of the level of difficulty of each problem statement.

Table 4

Ordering of Didactical Variables According to Their Level of Complexity

\begin{tabular}{|c|c|c|}
\hline \multicolumn{2}{|r|}{ Level of difficulty } & $\begin{array}{l}\text { Types of numerical relationships and elements of } \\
\text { information inclued in the statements }\end{array}$ \\
\hline \multirow{6}{*}{ 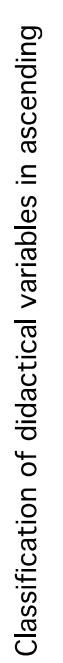 } & \multirow{6}{*}{  } & Noninteger relationship \\
\hline & & Superfluous elements of information \\
\hline & & Essential data \\
\hline & & Integer within relationship \\
\hline & & Situationa; elements of information \\
\hline & & Integer between relationship \\
\hline
\end{tabular}

\section{Exploration of the Impact of Belonging to a Class}

Finally, we verified if belonging to a class supervised by a specific homeroom teacher had any impact on the resolution of problems on proportions. To this end, we performed an analysis of variance (ANOVA). Also, to meet the conditions of application of ANOVA, we assessed the homogeneity of the data by performing Levene's test. Results of those tests are shown in Tables 5 and 6.

Based on the data yielded by our ANOVA, we can conclude that the performance of the students in problem-solving was influenced by the sixth-grade class to which they belonged $(F=3.999 ; p \leq 0.001)$. Also, Cohen (1988) states that the portion of the variance in problem-solving explained by the school environment is quite significant $\left(\eta^{2}=0,168\right)$. A subsequent analysis of covariance (ANCOVA) revealed that these class-based 
differences in performance were partialy caused by the students' socioeconomic environment $(\mathrm{F}=2.882 ; \mathrm{p} \leq$ $0.001 ; \eta^{2}=0,118$ ). The results of the ANCOVA are presented in Table 7 .

Table 5

Results of Levene's Test

\begin{tabular}{lllll}
\hline Dependant variables & Levene's statistics & Df1 & Df2 & Sig. \\
\hline Total Results & 1,085 & 25 & 496 & 0,356 \\
\hline
\end{tabular}

Table 6

Results of the ANOVA for the Success Rate in Resolution of Problems on Proportions as Obtained by Every Class

\begin{tabular}{|c|c|c|c|c|c|c|c|}
\hline & & Sum of squares & $\mathrm{df}$ & Mean square & $\mathrm{F}$ & Sig. & Effect size \\
\hline Total Results & $\begin{array}{l}\text { Between groups } \\
\text { Within groups } \\
\text { Total }\end{array}$ & $\begin{array}{l}8276 \\
41056 \\
49332\end{array}$ & $\begin{array}{l}25 \\
496 \\
521\end{array}$ & $\begin{array}{l}331,044 \\
82,776\end{array}$ & 3,999 & 0,000 & 0,168 \\
\hline
\end{tabular}

Table 7

Results of the ANCOVA for the Success Rate in Resolution of Problems on Proportions as Obtained by Every Class

\begin{tabular}{|c|c|c|c|c|c|c|c|}
\hline & & Sum of squares & $\mathrm{df}$ & Mean square & $F$ & Sig. & Effect size \\
\hline \multirow{4}{*}{ Total results } & Between groups & 5487 & 23 & & \multirow{4}{*}{2,882} & \multirow{4}{*}{0,00} & \multirow{4}{*}{0,118} \\
\hline & Within groups & 41056 & 496 & 238,589 & & & \\
\hline & Total & 497957 & 522 & 82,776 & & & \\
\hline & Corrected total & 49332 & 521 & & & & \\
\hline
\end{tabular}

\section{Data Interpretation}

We think that the results of this research project tend to confirm that the "contract hypothesis" is the most appropriate interpretative perspective to explain the learning difficulties in mathematics experienced by students with difficulties. This conclusion is reached because the characteristics of the students, operationalized by the use of the "at-risk student" label, have little influence over the efficiency of the relational calculus used to solve the problems on proportions. In only two problems out of nine did the undiagnosed students use more efficient procedures than at-risk students. This conclusion challenges the validity of the "specificity hypothesis", because demonstrating that the nature of the procedures used by the various categories of students did not differ implies that teachers do not need to adapt their interventions to the characteristics of their students.

We have demonstrated that the structure of the problems and the student's sense of belonging to a school environment have significant impact on his/her performance. These results support the "contract hypothesis" by arguing that various didactic considerations influence the relational calculus of sixth-grade students. Consequently, we suggest that the difficulties in solving problems on proportions experienced by students be interpreted based on their interactions with the school system in which they operate and the specificity of the knowledge involved. Our results challenge the very basis of the ministerial directives that recommend educators take action according to the psychological characteristics of the students.

Further research in didactics of mathematics is required to better understand the teaching of proportional reasoning to at-risk students. Thus, we suggest the exploration of the various didactic phenomena likely to happen in a class where inclusive education is encouraged. 


\section{Conclusion}

In conclusion, the research results show that the mathematicals learning difficulties of at-risk students should be interpreted by considering the role of school system in the emergence of those difficulties. To this end, we should give formation to primary school teachers in order to help them to analyse their own practices and think about the impact of their pedagogy. Moreover, our results show that the learning difficulties in mathematics should not be interpreted though a psychological perspective. In fact, our research demonstrates that at-risk students adopt the same mathematicals reasoning and the same mistakes of the normal achieving students. The only thing that differs between those two types of children is the number of mistakes. Consequently, we suggest that teachers do not have to adapt their interventions in class to the characteristics of the at-risk students.

\section{References}

Cohen, J. (1988). Statistical power analysis for the behavioral sciences. Hillsdale: Lawrence Erlbaum.

Deblois, L. (2011). Enseigner les mathématiques: des intentions à préciser pour planifier, guider et interpréter (Teaching mathematics: Intents to precise in order to planify, guide and interpret). Sainte-Foy: Presses de l'Université Laval.

Giroux, J. (2007). Adapter l'enseignement en classe d'adaptation scolaire (La TSD à la rescousse des difficultés d'enseignement aux élèves en difficulté d'apprentissage) (Adapting the teaching to special class (The TSD to overcome the teaching difficulties to the students with learning difficulties)). Entre didactique et politique: Actualités de la Théorie des Situations Didactiques à propos de quelques questions vives sur l'enseignement des mathématiques à l'école élémentaire (Between didactics and politics: Current development of the theory of didacticals situations about some importants questions on the mathematics teaching in primary school), Contribution au Symposium Bordeaux 2, mai 2007.

Giroux, J. (2010). Pour une différenciation de la dyscalculie et des difficultés d'apprentissage en mathématiques (For a differenciation of the dyscalculy and the learning difficulties in mathematics). Moncton: Actes de colloque du GDM.

Goupil, G. (2007). Les élèves en difficulté d'adaptation ou d'apprentissage (3rd ed.) (Students with adaptation difficulties or learning difficulties). Montréal: Gaétan Morin.

Gouvernement du Québec. (1999). Une école adaptée à tous les élèves. Politique de l'adaptation scolaire (A school for all students. Special class policy). Québec: Ministère de l'Éducation du Québec.

Gouvernement du Québec. (2006). L'évaluation des apprentissages au secondaire, Cadre de référence (Evaluation of learning at secondary school, Interpretative Framework). Québec: Ministère de l'Éducation, du Loisir et du Sport.

Lemoyne, G., \& Lessard, G. (2003). Les rencontres singulières entre les élèves présentant des difficultés d'apprentissage en mathématiques et leurs enseignants (Meeting among students with learning difficulties in mathematics and their teachers). Éducation et francophonie, 21(2). Retrieved $\quad 2011$, September $30 \quad$ from http://www.acelf.ca/revue/revuehtml/31-2/01-lemoyne.html

Martin, V., \& Mary, C. (2010). Particularités de l'enseignement des mathématiques à des élèves en difficulté en classes régulières ou spéciales (Specificities of teaching mathematics for children in difficulties in regular clases or specials classes). Moncton: Actes du colloque du GDM. Université de Moncton.

Mary, C., Squalli, H., \& Schmidt, S. (2008). Mathématiques et élèves en difficulté grave d'apprentissage: Contexte favorable à l'intégration et au raisonnement mathématique (Mathematics and students with severe learning difficulties: Emergence context to mathematical reasoning). In J. M. Bisaillon and N. Rousseau (Eds.), Les jeunes en difficulté: Contextes d'intervention favorables (Youth people in difficulties: Interventions contexts). Québec: Presses de l'Université du Québec.

Ministère de l'Éducation du Québec. (2000a). Trouble de déficit de l'attention/hyperactivité: rapport du comité-conseil sur le trouble de déficit de l'attention/hyperactivité et sur l'usage de stimulants du système nerveux central (Attention deficit disorder: Report of the comity of the ADHD disorder). Québec: Gouvernement du Québec.

Ministère de l'Éducation du Québec. (2000b). Élèves handicapés ou élèves en difficulté d'adaptation ou d'apprentissage (EHDAA): définitions (Students with handicap or in adaptation difficulties or learning difficulties: Definitions). Québec: Direction de l'adaptation scolaire et des services complémentaires. 
Perrin-Glorian, M. J. (1993). Questions didactiques soulevées à partir de l'enseignement des mathématiques dans des classes « faibles » (Questions about mathematicals teaching in «weak » classes). Recherche en didactique des mathématiques, 13(1/2), $5-18$.

Roiné, C. (2009). Cécité didactique et discours noosphériens dans les pratiques d'enseignement en S.E.G.P.A: Une contribution à la question des inégalités. (Didactic blindness and discourses about teaching practices in S.E.G.P.A: A contribution to the inegality question) (Thèse inédite (Unpublished thesis)). Bordeaux: Université Victor Segalen Bordeaux 2.

Squalli, H., Venet, M., \& Lessard, A. (2006). Intervention auprès de l'élève à risque: approches multiples et différenciées (Interventions to at-risk students: Differenciated approaches). Nouveaux cahiers de la recherche en éducation, 9(2), 119-122. 